\title{
PARASITIC INFESTATION AND ITS EFFECT ON GROWTH OF PRIMARY SCHOOL CHILDREN IN HEHIA CENTER, ZAGAZIG CITY, SHARKIA GOVERNORATE
}

Heba Said Abdelrhman Mohammed ${ }^{(1)}$ Amal Mohamed Eldakhakhny ${ }^{(2)}$ Bataa Mahmoud Mohammed ${ }^{(3)}$

${ }^{(1)}$ Nursing specialist in nursing science, Hehia Hospital, ${ }^{(2)}$ Professor of Pediatric Nursing, Faculty of Nursing ,Zagazig University, ${ }^{(3)}$ Lecturer of Pediatric Nursing, Faculty of Nursing,Zagazig University

\begin{abstract}
Background: Intestinal parasitic infestations are one of the neglected tropical diseases and it is most common among school children. It negatively affects children growth, cognitive development and learning abilities. It may lead to nutritional deficiencies and anemia. The present study aims to identify the effect of parasitic infestations on growth among primary school children. Descriptive comparative design was conducted on a sample of 200 children (100 infected study group, and 100 not infected) at Hehia primary schools. Two tools were used; Questionnaire interview sheet and Growth Chart. The study results revealed that $118.46 \pm 10.49$ was the mean of height of not infected group. Also, $31 \%$ of not infected group were in underweight level; It can be concluded that there was a statistically significant difference between both not infected and infected group concerning to weight and body mass index. Also, there was a statistically significant difference between both group concerning to body mass index levels therefore the study recommended that health education and environmental sanitation improvement are recommended as preventive control measures.
\end{abstract}

Keywords: Parasitic infestation, school children and growth

\section{Introduction:}

Children are vulnerable group in the community, their health is vital to the future of society. School age is segment of life span that extends from age 6- 12 years of age. School children are main target to many health problems such as malnutrition, non-infectious diseases and infectious diseases as intestinal parasitic diseases ${ }^{(1)}$.

Gastrointestinal parasites are microorganisms that live in the intestine, some cause problem while others can live for long periods in the bowel without causing any symptoms or require treatment.

Gastrointestinal parasite and severity of its infections have a profound impact on human public health and development, affecting approximately one-third of the world's population, causing high mortality rate mostly in children. They can be largely categorized into two groups, protozoans (e.g. Entamoeba histolytical, Giardia duodenalis) and helminthes (e.g. Ascaris lumobricoides). These GIPs flourish in settings characterized by warm temperature, humidity, poor sanitation, dirty water and crowded housing ${ }^{(2)}$.

(3) Mentioned that in developed countries, protozoan parasites more commonly cause gastrointestinal infections compared to helminthes. As well as WHO estimates, at least 2 billion people worldwide are infected with helminthes and of these approximately 300million suffer associated severe morbidity ${ }^{(4)}$.

The public health impact of parasitic infection has been consistently 
underestimated in the past, but there is now a general consensus that diseases caused by intestinal parasites represent an important public health problem, especially children. Recent studies suggest that even moderate intensity of infection may have adverse effects on growth, iron deficiency anemia and cognitive function, practically for children of school age ${ }^{(5)}$.

These adverse health consequences combine to impair childhood educational performance, reduce school attendance and subsequent productivity; also, these affect their physical development and may also prevent them from taking full advantage of their opportunity for formal school education ${ }^{(6)}$.

Fortunately,parasitic infestations are preventable thus pediatric health care providers can play an important role for prevention, early detection and management of parasitic infection and its complications ${ }^{(7)}$.

Also, School health nurse has important role in the prevention and control of parasitic diseases. She educates children and trains them in their care and about personal hygiene measures such as: keeping finger nails short, avoiding scratching of perianal area and nail biting. As well as wash hands as good hand hygiene is the most effective preventive measures especially after using the bath room and before eating and avoid sucking thumb, especially for Ascriasis. Moreover encourage children to wear shoes and avoid going barefoot, especially for Ancylostoma duodenal ${ }^{(1)}$.

Therefore the objective of this study was to recognize the effect of parasitic infestations on growth among primary school children .The findings of this study might help in strengthening the information available so far and encourage policy makers to design effective strategies to prevent intestinal parasitic infections in the study area.

\section{Significance of the Study:}

School children are the prime victims of intestinal parasitic infections that affect their physical development, reproductive health, school attendance and ability to learn, as they cause iron deficiency anemia, mental health problems and cognitive performance of school age children. So this study will examine the effect of parasitic infestations on growth and school achievement among primary school children and great attention should to be taken especially by the pediatric nurse during the follow up and treatment.

\section{The aim of the study was:}

To assess the effect of parasitic infestations on growth among primary school children at Hehia primary schools.

\section{Research questions:}

- What is the effect of parasitic infestations on growth among primary school children?

\section{Subjects and Methods:}

\section{Research design:}

Descriptive comparative design was used to identify the effect of parasitic infestations on growth among primary school children.

\section{Study Setting:}

The study was conducted at Hehia primary schools. Positive responses were received from 25 schools. Three schools were finally included in the study, with selection based on (I) size in terms of the number of students; (II) geographical location; (III) representation of the different target communities; and (IV) commitment to support the project activities.

\section{StudySubjects:}

The subjects of this study were composed of two main groups:

Group I: Study group:

A convenient sample of children amounted to 100 children who fulfill the following criteria constituted the sample:

Age: from 6-12 years.

Both sexes. 


Free from any other diseases
except complications of parasitic
infections.
Group II: Control group:
Matching sample of healthy children
of the current study composed of 100
primary school children, who met the
inclusion criteria,
Age: from (6 to 12)
Both sexes (male \&female)
Free from any parasitic diseases,
infections, injury and deformity.

\section{Tools for data collection}

Two tools were used in this study:

\section{Tool I: A structured interview questionnaire sheet:}

A structured interview questionnaire sheet was developed by the researcher under supervision of the supervisors after reviewing relevant scientific literature and articles to collect the required data. It consisted of the following parts:

Part A: Personal characteristics of studied children such as child's name, age, sex, birth order, class, number of siblings and crowding index (question 1-7).

Part B: Information about the child's family such as personal characteristics of parents, age, level of education and job, amount of time spend with child and family income (question 8-11).

Part C: Information about the child and disease (i) child health including which the child suffering from any disease, any investigations can be done.......etc (question 12-17). (ii) child's health practice including washing hands before and after eating and after using toilet, cleaning fruits and vegetables before eating.......etc (question 17-24). (iii)Information of the child about the disease including the meaning of paraite,types of it, it's diagnosis, insects that can transmit it...........etc (question 25-33).

Tool II: Growth Chart:

Developed by The National Center For Health Statistics In Collaboration With
The National Center For Chronic Disease Prevention And Health Promotion (2000). The growth charts show the weight status categories used with children and teens (underweight, healthy weight, overweight, and obese).

\section{$>$ For the anthropometric measurements:}

Required Equipment:

For measuring weight, use a properly calibrated balance-beam or strain-gauge floor scale (mechanical or digital) that:

$\square$ can weigh in 0.1 kilogram or $1 / 4$ pound increments;

$\square$ has a stable platform;

$\checkmark$ has the capacity to be "zeroed" after each weight is taken; and

$\square$ has the capacity to be calibrated.

For measuring height, use a stadiometer that:

$\square$ is able to read to 0.1 centimeter or $1 / 8$ inch;

$\checkmark$ has a large stable base; and

has a horizontal headpiece that is at least 3 inches wide that

Can be brought into contact with the most superior part of the head (i.e., the crown).

$\square$ Movable headpieces which are attached to balance-beam scales are not recommended for use.

Body weight was measured once to the nearest $0.1 \mathrm{~kg}$. Body height was taken to the nearest $0.1 \mathrm{~cm}{ }^{(8)}$. Body mass index is a measure of body fat based on height and weight, Body mass index is a measure of body fat based on height and weight, The Body Mass Index (BMI) of each patients was calculated by the $(\mathrm{BMI}=$ weight $(\mathrm{kg})$ divided by the height $(\mathrm{m} 2)$. The World Health Organization classified adults as obese $(\mathrm{BMI}>30)$, overweight $(\mathrm{BMI}=25$ $29.99)$ and normal $(\mathrm{BMI}=18.50-24.99){ }^{(9)}$. Field work:

Upon securing all official permissions, the process of data collection was started from October 2016 to January 2017. The researcher first introduced herself and explained the purpose of the research 
briefly to all children who were infected by parasitic infestations. Each child was interviewed individually in the class after explanation the purpose of the study and takes their oral consent, and the researcher read each item of the study questionnaire. The time consumed for answering the study questionnaire ranged from 20-30 minutes. The researcher performed the fieldwork three days weekly (Saturday, Monday and Wednesday). Pilot study:

It was carried on $10 \%$ of children assess the applicability of the data collection tool, arrangement of items, estimate the time needed for filling the sheets with the collected data and feasibility of the study and acceptance to be involved in the study. Administrative Design:

An official request to conduct the study was directed from faculty of Nursing, Zagazig University to directors of three primary schools at hehia city. It was done by obtaining an official permission from the directors of schools in which the study will be conducted.

\section{Ethical considerations:}

A simple explanation about the aims of the study was illustrated to the teachers and students. The verbal consent was first obtained both from the teachers and students and then students were selected by systematic random sampling using the master list of the schools .Oral consent notifying children's agreement to share in this study. The researcher emphasized in the consent that the participation was voluntary, and any participant can withdraw at any time without any need to justify his/her decision, any raised question will be answered, and the collected data will be treated confidentially and will be used only in the current study.

Statistical analysis:

Collected data were coded, computed and statistically analyzed using SPSS (statistical package of social sciences), version 16. Data were presented as frequency and percentages (qualitative variables) and mean \pm SD (quantitative continuous variables). Chi square $(\square 2)$ was used for comparison of categorical variables, and was replaced by Fisher exact test (FET) or Mont Carlo Exact test if the expected value of any cell was less than 5. Student's $t$ test was used for comparison of continuous quantitative variables (two groups) and one way anova (F test) was used for comparison of continuous quantitative variables (more than two groups). For continuous quantitative variables which were not normally distributed, Median was used as a central tendency measures and Mann Whitney test (Z) was used for comparison of two groups. The difference was considered significant at $\mathrm{P} \leq 0.05$.

Results:

Table (1): The characteristics of studied school children which revealed that $54 \%$ of not infected group at the age of 9 years to less than 10 compared to $56 \%$ of infected group with mean age $7.73 \pm 1.50$ years. The same table illustrated that $50 \%$ of not infected group were males; compared to $65 \%$ of infected group.

Concerning to birth order, it was found that $41 \%$ of not infected group was the first order in their family compared to $36 \%$ of infected group. Also, it was found that $55 \%$ of not infected group was at the 4 th school class compared to $56 \%$ of infected group.

Regarding to crowding index, it was found that $92 \%$ of not infected group had crowding index up to 2 compared to $68 \%$ of infected group.

Table (2): clarifies family characteristics of the studied school children. It was found that $53 \%$ of not infected school children's mothers at the age of $\geq 30$ years children compared to $62 \%$ of infected group mothers. Concerning to mothers' education it was found that $43 \%$ and $18 \%$ respectively of not infected and infected 
groups their mothers had finished their university education level. Regarding to mothers job, it was found that 59\% \& $74 \%$ of both groups' were not working.

Regarding to fathers age, it was found that there was $61 \%$ of not infected group at the age of $\geq 30$ years compared to $78 \%$ of infected group. As for fathers education both groups' fathers had university education level presented by $47 \%$ and $18 \%$ respectively. Concerning to fathers job, it was found that $37 \% \& 64 \%$ of both groups respectively were with free jobs.

Table (3) clarifies medical history of the disease among the studied school children, regarding to suffering from any disease it was found that $73 \%$ of not infected group was not suffering from any disease compared to $3 \%$ of infected group. Regarding to types of these diseases, it was found that $92 \%$ of these diseases were intestinal parasites mainly of infected group and only $1.0 \%$ of not infected group.

Concerning to doing stool analysis, it was found that $78 \%$ of not infected group had done stool analysis compared to $87 \%$ of infected group. The same table also revealed that $65 \%$ of infected group had positive stool results compared to $28 \%$ of not infected group. Regarding to taking treatment for previous infection, it was found that $61 \%$ of infected group was talking treatment compared to $29 \%$ of not infected group.

It was found that $66 \%$ of infected group had parasitic infection in their family compared to $34 \%$ of not infected group. As well as it was found that those infection mainly from brothers and sisters in both infected group and not infected group which represented by $49 \% \quad \& 16 \%$ respectively.

Table (4): clarified Healthy Behaviors of the Studied School Children. It was found that there was statistical significant difference between infected and non- infected students regarding all healthy behaviors $(\mathrm{p}<0.05)$.

Table (5): demonstrated average weight, height and total BMI among studied children. There was a statistically significant difference between both not infected and infected group concerning to weight $(\mathrm{P}=0.000)$ and body mass index $(\mathrm{p}=0.001)$. Table $(6)$ : demonstrated body mass index levels of the studied children. There was a statistically significant difference between both infected and not infected group concerning to body mass index levels $(\mathrm{p}=0.00)$.

\section{Discussion:}

"School-age" is very crucial for the development of healthy habits, lifestyle and behavior, therefore, an important joint venture of departments of education and health providing an opportunity to implement primary and secondary prevention at the same time to a large number of children Kulkarni et al. ${ }^{(11)}$.

Carter ${ }^{(12)}$ stated that student achievement measures the amount of academic content student learns in a determined amount of time, each grade level has learning goals or instructional standards that educators are required to teach.

Parasites are organisms that are dependent upon a particular species of host and may be seen either macroscopically (by the naked eye) or with the aid of a microscope (microscopically). As well as parasite depends upon the host for its nutrients and the true parasites obtain their nutrients at the expense of the host. Some parasites of humans cause little or no physical harm, whereas others cause severe disease and death Ridley ${ }^{(13)}$.

Regarding the characteristics of studied school children, the current study mentioned that more than half of studied group at the age of 9 years to less than 10 years. These results were supported by Suntaravitun and Dokmaikaw ${ }^{(14)}$ who revealed that the overall infection rate was highest among 9 years age group. On the 
other hand, This result is in contrast with the study conducted in Morocco who showed that the age distribution of the prevalence of infection rate was highest among the children aged more than 10 years Messaad et al (15) Also, these findings was disagreed Gyang et al (16) who found that the association of age with infection was not significant; all age groups were almost equally exposed. These may be due to that this age had more activities in contact with water and earth. Regarding to sex of studied children, the present study showed that the majority of infected children were males. The difference in parasitic infections between sexes that is higher in males than females could be due to modes of transmission of the parasites, sample size determination, study population and the methods used could attribute to this observed difference in detections of various parasites. These results disagreed with Maru (17) who found that, higher infection prevalence was in females than males. These results are in agreement with El-Nadi et al ${ }^{(18)}$ who found that males were more affected than females.

Bauomy et al ${ }^{(19)}$ who reported that about one half of studied students had previous history of parasitic infection, which was matched with the present study which revealed that more than three quarter of the studied students suffered from previous disease mainly parasitic infection. This may be due to not fully developed immune systems among school children in addition to their playing and poor hygiene practices put them at frequent risk of infection. Also, these results was in agreement with the study done in Tanta by Ahmed (20) who demonstrated that about one quarter of school pupils had previous intestinal parasitic infections.

The present study showed that the majority of studied children didn't wash their hands after\& before eating or after defecation. This is probably due to low knowledge of children mainly about the faecal-oral transmission of intestinal parasite through their unwashed hands, or perhaps, due to lack of hand washing facilities close to lavatory. This result was matched with Ahmed et al (21) who reported that the majority of the studied children hadn't washed their hands after defecation. Also, Kattula et al ${ }^{(22)}$ who postulated that intestinal parasites spread through poor hygienic practices, evidenced by contaminated finger nails and unclean hands. The results of this study also showed that malnutrition (which can be detected by BMI levels) is common among the study subjects. These results stated that more than half of studied group were under weight .This results is in consistent with Ahmed et al (23) who found that higher prevalence of malnutrition among participant. This malnutrition may be due to the low socioeconomic status of most of the households, which affect the dietary intake. These results is in contrast with El-Sehry et al (1) who mentioned that parasitic infection was recent and their bad impact didn't develop on infected students and the majority of the studied students were at normal weight. the present study showed that there was highly statistically significant difference between both groups concerning to body mass index levels $(\mathrm{p}=0.00)$. These results 'disagreed with Gyang et al (16) who found that there was no association was found between the BMI and infection in the univariate or multivariate logistic regression analyses $(p \geq 0.05)$.Also, there was statistically significant difference between both groups concerning to weight and body mass index. This finding goes in line with Alwabr \& Al-Moayed (24) who mentioned that the anthropometrical measurements revealed that the children of Al-Mahweet Governorate were shorter and lighter than 
WHO standards. .These results was in contrast with Ojurongbe et al ${ }^{(25)}$ who studied soil transmitted helminth infections among primary school children in Ile-Ife Southwest, Nigeria and stated that no significant difference between the weight and height of the pupils that were infected and uninfected with helminth infection. The findings of the present

Table (1): Characteristics of the Studied School Children

\begin{tabular}{|c|c|c|c|c|c|}
\hline \multirow{2}{*}{ Characteristics } & \multicolumn{2}{|c|}{$\begin{array}{c}\text { Not Infected } \\
(100)\end{array}$} & \multicolumn{2}{|c|}{ Infected(100) } & \multirow[t]{2}{*}{$\begin{array}{c}\text { Significance } \\
\text { test }\end{array}$} \\
\hline & No & $\%$ & No & $\%$ & \\
\hline $\begin{array}{lll}\text { Age/years } & & \\
& \bullet & 6 \\
& \bullet & 7 \\
& \bullet & 9 \\
& \bullet & 10 \\
\end{array}$ & $\begin{array}{c}41 \\
3 \\
54 \\
2 \\
\end{array}$ & $\begin{array}{c}41.0 \\
3.0 \\
54.0 \\
2.0\end{array}$ & $\begin{array}{c}42 \\
1 \\
56 \\
1\end{array}$ & $\begin{array}{c}42.0 \\
1.0 \\
56.0 \\
1.0\end{array}$ & $\begin{array}{c}\chi^{2}=1.382 \\
P 0.710\end{array}$ \\
\hline Mean \pm SD & 7.73 & 1.50 & & \pm 1.50 & ------------------ \\
\hline $\begin{array}{ll}\text { Sex } & \\
\bullet & \text { Males } \\
\text { - } & \text { Females } \\
\end{array}$ & $\begin{array}{l}50 \\
50 \\
\end{array}$ & $\begin{array}{l}50.0 \\
50.0 \\
\end{array}$ & $\begin{array}{l}50 \\
50 \\
\end{array}$ & $\begin{array}{l}65.0 \\
35.0 \\
\end{array}$ & $\begin{array}{c}\chi^{2}=4.604 \\
\text { P } 0.032^{*}\end{array}$ \\
\hline 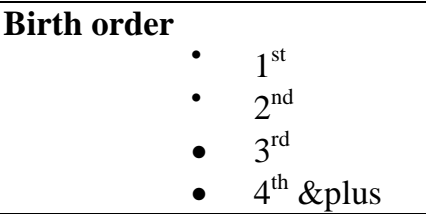 & $\begin{array}{c}41 \\
39 \\
12 \\
8\end{array}$ & $\begin{array}{c}41.0 \\
39.0 \\
12.0 \\
8.0\end{array}$ & $\begin{array}{c}36 \\
35 \\
26 \\
3\end{array}$ & $\begin{array}{c}36.0 \\
35.0 \\
26.0 \\
3.0\end{array}$ & $\begin{array}{c}\chi^{2}=7.972 \\
\mathrm{P} 0.047^{*}\end{array}$ \\
\hline $\begin{aligned} & \text { School grade } \\
& \bullet 1 \mathrm{st} \\
& \bullet 2 \mathrm{nd} \\
& \bullet 3 \mathrm{rd} \\
& \bullet 4^{\text {th }} \\
&\end{aligned}$ & $\begin{array}{c}43 \\
2 \\
0 \\
55\end{array}$ & $\begin{array}{c}43.0 \\
2.0 \\
0.0 \\
55.0\end{array}$ & $\begin{array}{c}43 \\
0 \\
1 \\
56\end{array}$ & $\begin{array}{c}43.0 \\
0.0 \\
1.0 \\
56.0\end{array}$ & $\begin{array}{c}\chi^{2}=3.009 \\
\text { P } 0.390\end{array}$ \\
\hline $\begin{array}{r}\text { Family number } \\
\bullet \quad 3 \\
\bullet \quad 4 \\
\bullet \quad 5 \\
\bullet \quad 6 \\
\bullet \quad 7\end{array}$ & $\begin{array}{c}10 \\
43 \\
31 \\
15 \\
1\end{array}$ & $\begin{array}{c}10.0 \\
43.0 \\
31.0 \\
15.0 \\
1.0\end{array}$ & $\begin{array}{l}6 \\
27 \\
47 \\
20 \\
0\end{array}$ & $\begin{array}{l}6.0 \\
27.0 \\
47.0 \\
20.0 \\
00.0\end{array}$ & $\begin{array}{c}\chi^{2}=9.653 \\
\mathrm{P} 0.047^{*}\end{array}$ \\
\hline - $\quad$ Mean \pm SD & & $4 \pm 0.9$ & & $4.81 \pm 0.81$ & $\begin{array}{l}\mathrm{t}=2.207, \\
\mathrm{P} 0.028^{*}\end{array}$ \\
\hline $\begin{aligned} \text { Crowding Index } & \\
\bullet & \text { Up to } 2 \\
\bullet & >2\end{aligned}$ & $\begin{array}{l}92 \\
8\end{array}$ & $\begin{array}{l}92.0 \\
8.0\end{array}$ & $\begin{array}{l}68 \\
32\end{array}$ & $\begin{array}{l}68.0 \\
32.0\end{array}$ & $\begin{array}{c}\chi^{2}= \\
17.910 \\
\text { P } 0.000^{*}\end{array}$ \\
\hline Mean \pm SD & & $9 \pm 0.4$ & & $2.01 \pm 0.47$ & $\begin{array}{l}t=4.937 \\
P 0.000\end{array}$ \\
\hline
\end{tabular}

study may be due to STH infections which were recognized as a major contributor to malnutrition which could influence the weight, height and BMI of infected subjects. Also, this might be due to chronic IPI infection supplemented with appetite reduction, absorption problems, with chronic food insecurity. 
Table (2): Family Characteristics of the Studied School Children

\begin{tabular}{|c|c|c|c|c|c|}
\hline \multirow[t]{2}{*}{ Characteristics } & \multicolumn{2}{|c|}{$\begin{array}{c}\text { Not } \\
\text { Infected } \\
\text { (100) }\end{array}$} & \multicolumn{2}{|c|}{$\begin{array}{c}\text { Infected } \\
\text { (100) }\end{array}$} & \multirow[t]{2}{*}{$\begin{array}{c}\text { Significance } \\
\text { test }\end{array}$} \\
\hline & No & $\%$ & No & $\%$ & \\
\hline \multicolumn{6}{|l|}{ Mothers' age /years } \\
\hline - $\quad<30$ years & 47 & 47.0 & 38 & 38.0 & $\chi^{2}=1.657$ \\
\hline - $\quad \geq 30$ & 53 & 53.0 & 62 & 62.0 & P 0.198 \\
\hline \multicolumn{6}{|l|}{ Mothers education } \\
\hline - Illiterate & 13 & 13.0 & 34 & 34.0 & \\
\hline - Basic & 13 & 13.0 & 16 & 16.0 & $\chi^{2}=19.955$ \\
\hline - Secondary & 31 & 31.0 & 32 & 32.0 & P $0.000^{*}$ \\
\hline - University & 43 & 43.0 & 18 & 18.0 & \\
\hline \multicolumn{6}{|l|}{ Mothers' job } \\
\hline - Working & 41 & 41.0 & 26 & 26.0 & $\chi^{2}=5.050$ \\
\hline - Not working & 59 & 59.0 & 74 & 74.0 & $\mathrm{P} 0.025^{*}$ \\
\hline \multicolumn{6}{|l|}{ Fathers 'age } \\
\hline - $\quad<30$ years & 39 & 39.0 & 22 & 22.0 & $\chi^{2}=6.817$ \\
\hline - $\quad \geq 30$ & 61 & 61.0 & 78 & 78.0 & P $0.009^{*}$ \\
\hline
\end{tabular}

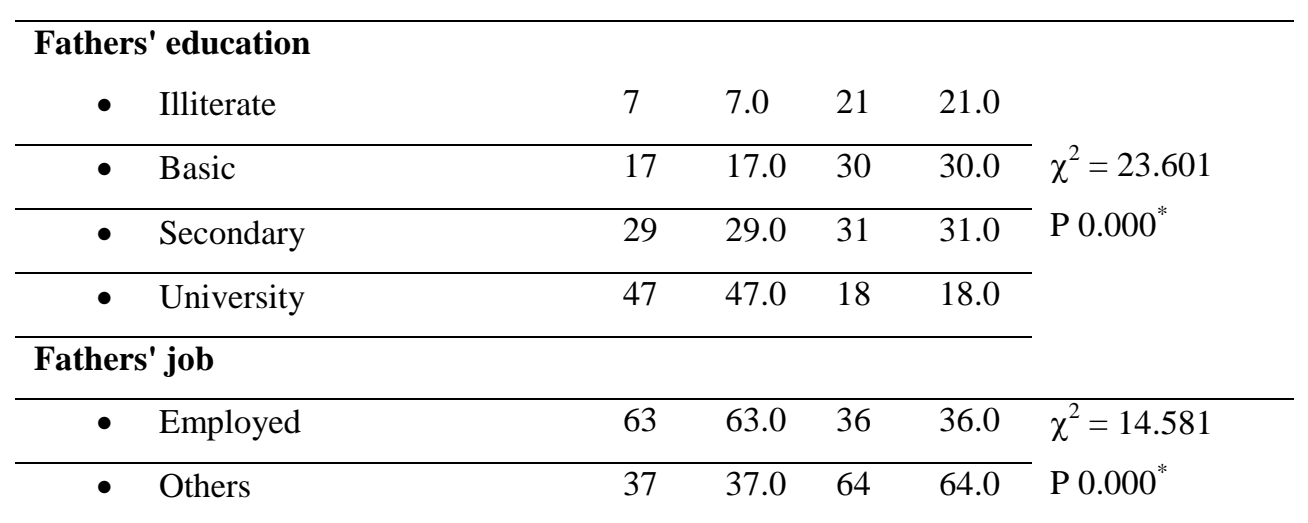

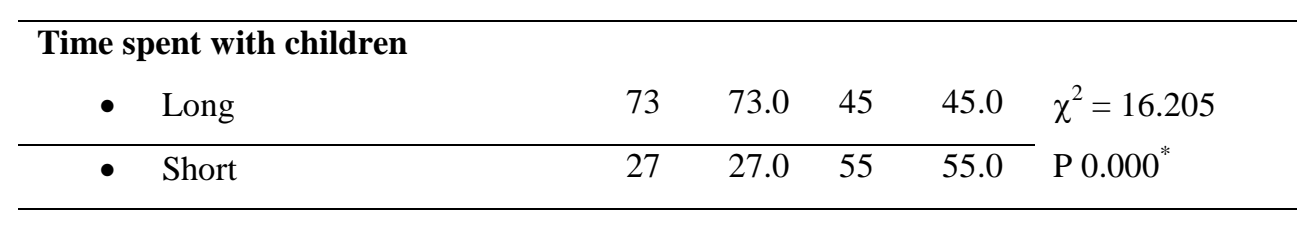


PARASITIC INFESTATION AND ITS EFFECT ON etc...

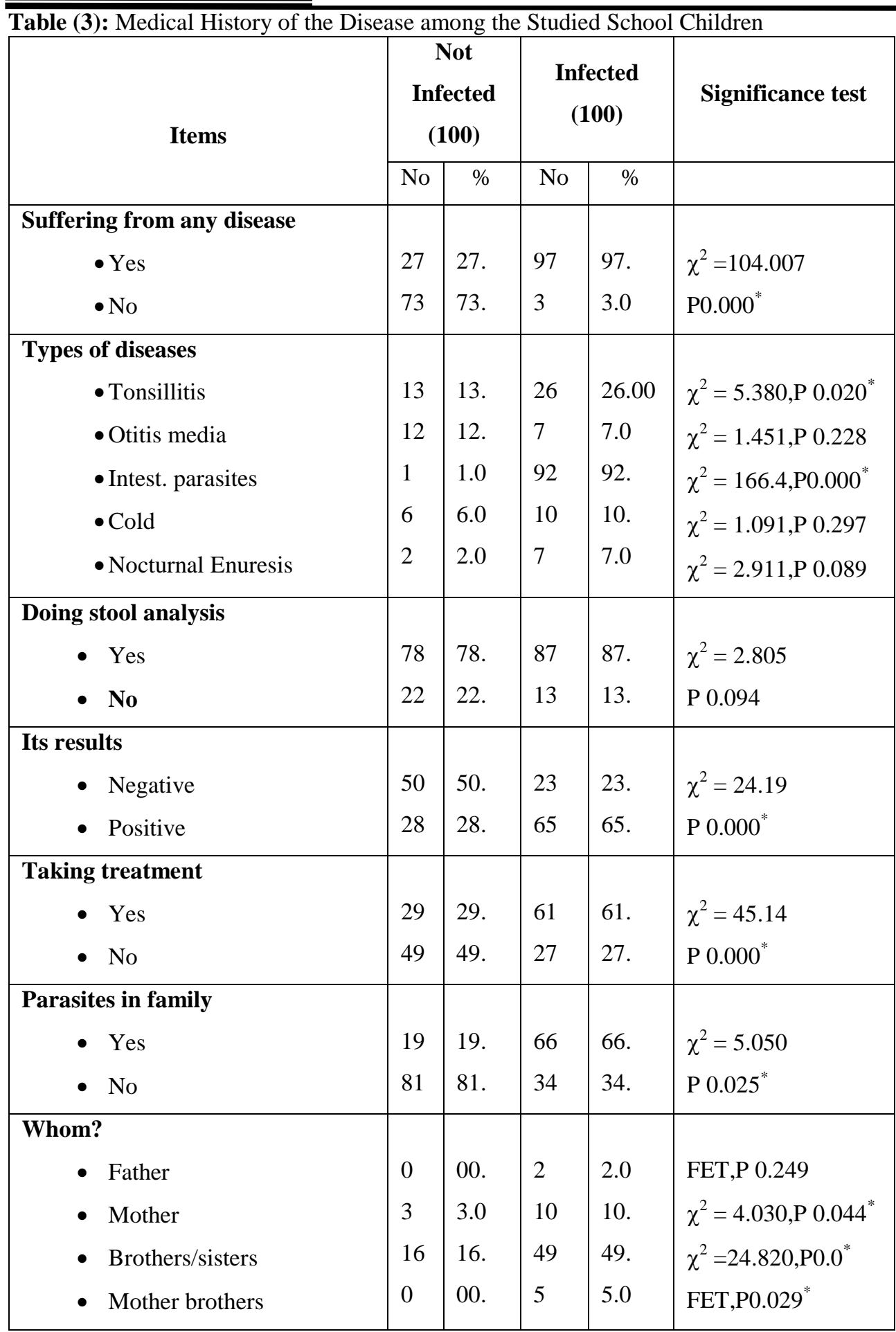


Table (4): Healthy Behaviors of the Studied School Children

\begin{tabular}{|c|c|c|c|c|c|}
\hline \multirow[t]{2}{*}{ Characteristics } & \multicolumn{2}{|c|}{$\begin{array}{c}\text { Not } \\
\text { Infected } \\
(\mathbf{1 0 0})\end{array}$} & \multicolumn{2}{|c|}{$\begin{array}{c}\text { Infected } \\
(100)\end{array}$} & \multirow[t]{2}{*}{ Significance test } \\
\hline & No & $\%$ & No & $\%$ & \\
\hline $\begin{array}{l}\text { Hand washing before \& after } \\
\text { eating } \\
\begin{array}{ll}\text { - } & \text { yes } \\
\text { - } & \text { No }\end{array}\end{array}$ & $\begin{array}{l}93 \\
7\end{array}$ & $\begin{array}{l}93.0 \\
7.0\end{array}$ & $\begin{array}{l}55 \\
45\end{array}$ & $\begin{array}{l}55.0 \\
45.0\end{array}$ & $\begin{array}{l}\chi^{2}=37.526 \\
P 0.000^{*}\end{array}$ \\
\hline $\begin{array}{l}\text { Hand washing after toilet } \\
\begin{array}{l}\text { - } \quad \text { Yes } \\
\text { - No }\end{array}\end{array}$ & $\begin{array}{l}89 \\
11\end{array}$ & $\begin{array}{l}89.0 \\
11.0\end{array}$ & $\begin{array}{l}44 \\
56\end{array}$ & $\begin{array}{l}44.0 \\
56.0\end{array}$ & $\begin{array}{l}\chi^{2}=45.449 \\
P 0.000^{*}\end{array}$ \\
\hline $\begin{array}{l}\text { Good washing of fruits } \\
\text { \&vegetables } \\
\text { - yes } \\
\text { - No }\end{array}$ & $\begin{array}{l}85 \\
15\end{array}$ & $\begin{array}{l}85.0 \\
15.0\end{array}$ & $\begin{array}{l}41 \\
59\end{array}$ & $\begin{array}{l}41.0 \\
59.0\end{array}$ & $\begin{array}{l}\chi^{2}=41.527 \\
P 0.000^{*}\end{array}$ \\
\hline $\begin{array}{l}\text { Eating from street vendors } \\
\begin{array}{l}\text { - } \text { Yes } \\
\text { - } \mathrm{No}\end{array}\end{array}$ & $\begin{array}{l}44 \\
56\end{array}$ & $\begin{array}{l}44.0 \\
56.0\end{array}$ & $\begin{array}{l}80 \\
20\end{array}$ & $\begin{array}{l}80.0 \\
20.0\end{array}$ & $\begin{array}{l}\chi^{2}=27.504 \\
P 0.000^{*}\end{array}$ \\
\hline $\begin{array}{l}\text { Presence of sewage system in } \\
\text { the house } \\
\text { - Yes } \\
\text { - No }\end{array}$ & $\begin{array}{l}99 \\
1\end{array}$ & $\begin{array}{l}99.0 \\
1.0\end{array}$ & $\begin{array}{l}87 \\
13\end{array}$ & $\begin{array}{l}87.0 \\
13.0\end{array}$ & FET, P $0.001^{*}$ \\
\hline $\begin{array}{l}\text { Presence of water taps in the } \\
\text { house } \\
\text { - } \quad \text { Yes } \\
\text { - No }\end{array}$ & $\begin{array}{l}99 \\
1\end{array}$ & $\begin{array}{l}99.0 \\
1.0\end{array}$ & $\begin{array}{l}84 \\
16\end{array}$ & $\begin{array}{l}84.0 \\
16.0\end{array}$ & FET, P $0.000^{*}$ \\
\hline $\begin{array}{l}\text { Wearing shoes outside home } \\
\text { - Yes } \\
\text { - No }\end{array}$ & $\begin{array}{l}94 \\
6\end{array}$ & $\begin{array}{l}94.0 \\
6.0\end{array}$ & $\begin{array}{l}52 \\
48\end{array}$ & $\begin{array}{l}52.0 \\
48.0\end{array}$ & $\begin{array}{l}\chi^{2}=44.749 \\
P 0.000^{*}\end{array}$ \\
\hline
\end{tabular}


PARASITIC INFESTATION AND ITS EFFECT ON etc...

\begin{tabular}{|c|c|c|c|}
\hline \multirow[t]{2}{*}{ Items } & $\begin{array}{c}\text { Not Infected } \\
(\mathbf{1 0 0})\end{array}$ & $\begin{array}{c}\text { Infected } \\
(\mathbf{1 0 0})\end{array}$ & \multirow[t]{2}{*}{ Significance test } \\
\hline & Mean \pm SD & Mean \pm SD & \\
\hline Weight (kg) & $29.27 \pm 6.93$ & $25.29 \pm 5.86$ & $\mathrm{t}=4.441, \mathrm{P} 0.000^{*}$ \\
\hline Height (cm) & $118.46 \pm 10.49$ & $116.17 \pm 7.76$ & $\mathrm{t}=1.175, \mathrm{P} 0.081$ \\
\hline Body Mass Index $\left(\mathrm{kg} / \mathrm{m}^{2}\right)$ & $20.91 \pm 4.75$ & $18.80 \pm 4.24$ & $\mathrm{t}=3.306, \mathrm{P} 0.001^{*}$ \\
\hline
\end{tabular}

Significant at $\mathrm{p}<0.05$

Table (6): Body Mass Index Levels of the Studied Children

\begin{tabular}{|l|l|l|l|l|l|}
\hline \multicolumn{1}{|c|}{\begin{tabular}{c} 
Body Mass Index \\
\multicolumn{1}{c|}{ Levels }
\end{tabular}} & \multicolumn{2}{c|}{ Not infected } & \multicolumn{2}{c|}{ Infected } & \multicolumn{1}{c|}{$\begin{array}{c}\text { Significance } \\
\text { Test }\end{array}$} \\
\cline { 2 - 5 } & \multicolumn{1}{|c|}{ No } & $\%$ & No & \multicolumn{1}{c|}{$\%$} \\
\hline Under weight & 31 & 31.0 & 60 & 60.0 & \\
Average weight & 52 & 52.0 & 30 & 30.0 & $\chi^{2}=16.979$, \\
Over weight & 9 & 9.0 & 5 & 5.0 & P $0.000^{*}$ \\
Obese & 8 & 8.0 & 5 & 5.0 & \\
\hline
\end{tabular}

Significant at $\leq 0.05$

Underweight: $<18.5(\mathrm{~kg} / \mathrm{m} 2)$

Average weight: $18.5-<25.0$

Over weight: $25.0-<30.0$

Obese: $\geq 30$

\section{References:}

1- El-sehry NKM, Fouda LM and Hassan LE Prevalence of parasitic Infections and its Effect on the Health Status of Primary School Children. IOSR Journal of Nursing and Health Science. 2017;6(4): 4152.

2- Odo G, Agw J, Ezea C, GC A and PO U . Prevalence of Intestinal Parasites among School Children in Uzo- Uwani Local Governemnt Area of Enugu State. International Journal of Research Studies in Microbiology and Biotechnology.2016; 2(2):7-14.

3- Hassan HA . Prevalence rate of intestinal parasites among schools children in Al-kalakla localityKhartoum state. Published Master's Thesis. Sudan University of Science and Technology. College of Graduate Studies. A dissertation submitted in partial fulfillment for the requirements of the degree of M.Sc. in Medical Laboratory Science (Parasitology and Medical Entomology). 2017; Page 1.

4- Iwunze JI, Amaechi AA, Iheme JN, Njoku FU and Odemenam CC. (Prevalence of Intestinal Parasites among Primary School Children in Obowo L.G.A of Imo State, Nigeria. American Journal of Environmental and Geoscience. 2017; 1(1): 29-33.

5- Ashok R, Giddi S \& Kesavaram V. Prevalence of Intestinal Parasitic Infection in School Going Children in Amalapuram, Andhra Pradesh, India. Shiraz E-Medical Journal. 2013; 14(4).p.16652.

6- Aniwada ACh, Uleanya ND, Igbokwe LN and Onwasigwe Ch. soil transmitted helminths; prevalence, perception and determinants among primary school children in rural enugu state, Nigeria. 
International Journal of Tropical Disease \&Health. 2016 ; 15(1): 1-12.

7- Mohammed SA, Elfeky OE, Shahen AM\&Abed NT(2014):Prevalence of Parasitic Infestation among Preschool children in Qualiobia with Feeding Problems, Unpublished master's thesis .Benha University. Faculty of Medicine. Pediatric department.p.4.

8- Müller I, Yap P, Steinmann P, Damons BP, Schindler Ch, Seelig $\mathrm{H}$, Walter $\mathrm{Ch}$. Intestinal parasites, growth and physical fitness of schoolchildren in poor neighborhoods of Port Elizabeth, South Africa: across-sectional survey. Journal of Parasites \& Vectors.2016; 9(488).

9- World Health Organization (WHO), (2017): Body mass index BMI. Retrieved (Feb21, 2017) from http://www.euro.who.int/en/healthtop ics/disease-prevention/nutrition/ahealthy-lifestyle/body-mass-indexbmi

10- Bartosh O (2003):Environmental Education Improving Student Achievement. available at:https://www.google.com.eg/search ?biw $=1366 \&$ bih $=643 \&$ q $=$ student + pe rformance + assessment + pdf + june +20 $03 \&$ oq $=$ student + performance + as . Accessed at 30March 2016.6:40 pm.

11- Kulkarni M, Varun N, Rathi P, Eshwari K, Ashok K\& Kamath V .Health Status of Children in Rural Area of Coastal Karnataka. Medical Journal of Dr D.Y.Patic University. 2016; 9(1):Pp31-35.

12- Carter V (2015): Student Achievement, Definition, Factor Research. Available at: http://wwwStudy.Com/academy/less on/student-achievement-definitionfactor-research.html. Accessed at 17 Feb 2016.9:15pm.

13- Ridley JW (2012): Background of parasitology. In: parasitology for medical and clinical laboratory professionals, 1st ed. Delmar Cen gage Learning. United States of America .P35.Available at: https://books.google.com.eg/books?i d=xewIAAAAQBAJ\&pg=PA3\&dq= Parasites+are+organisms+that+are $+\mathrm{d}$ ependent+upon+a+particular+specie

14- Suntaravitun P \&Dokmaikaw . A prevalence of intestinal parasitic infections and associated risk factors among school children in adigrat town, northern Ethiopia. Asian Pacific Journal of Tropical Disease. (2017); 7(9):523-526

15- Messaad SA, Laboudi M, Moumni M, Sarhane B, Belghyti D and El Kharrim KH .Children intestinal parasites related to socioeconomic factors in Salé hospital, Morocco. Int J Innov Appl Stud.2014; 8(2): 833 840.

16- Gyang VP, Chuang T, Liao Ch, Lee y, Akinwale OP, Orok A, Ajibaye O, Babasola A, Cheng $p$, Chou Ch, Huang Y, Sonko P \& Fan Ch. Intestinal parasitic infections: Current status and associated risk factors among school aged children in an archetypal African urban slum in Nigeria. Journal of Microbiology, Immunology and Infection.2017;1-8.

17- Maryo DS .Prevalence of Intestinal Parasitic Infections and Associated Risk factors among School children in Aigrette town, Northern Ethiopia. International Journal of Emerging Trends in Science and Technology.2017; 4(1): 4943-4948.

18- El-Nadi NAF, Omran EK, Ahmed NS, Fadel EF .Current status of intestinal parasites among elementary school children in Sohag, Egypt. Journal of Advances in Parasitology.2017; 4(2): 33-40.

19- Bayoumi M, Nykwac O, Kardaman M, Ullberg M \& Saeed A .intestinal Parasitic Infections in School 
Students in Malakal City, Upper Nile State, South Sudan. 2016. Available at:

chttps://www.google.com.eg/?gfe_rd =cr\&ei=zmknVobKMeLH8gfDjaeoC $\mathrm{g \# q=intestinal+parasitic+infestations}$ +pdf+2016.Acessed at 15 May 2016. $11 \mathrm{pm}$.

20- Ahmed W .Intestinal Parasites among Primary School Children in Urban and Rural Tanta, Gharbia, Governorate, Egypt. Journal of the Egyptian society of experimental biology. 2013; 9(2): $257-262$.

21- Ahmed Kh, Siraj NM, Fitsumberhan H, Isaac H, Yohannes S, Eman D, Berhane $\mathrm{Y}$ and Araya M .Knowledge, Attitude and Practice (KAP) Assessment of Intestinal Parasitic Infection among School Children in Asmara, Eritrea. Health journal.2017; 9 (1):57-68.

22- Kattula D, Sarkar R, Ajjampur SS, Minz Sh, Levecke B, Muliyi J\& Kang J. Prevalence \& risk factors for soil transmitted helminth infection among school children in south India. Indian J Med Res.2014; 139: 76-82.
23- Ahmed A, Al-Mekhlafi HM, AlAdhroey AH, thoi L, Abdulsalam $\mathrm{AM}$ and Surin J. The nutritional impacts of soil-transmitted helminths infections among Orang Asli schoolchildren in rural Malaysia; Journal of Parasites \& Vectors. 2012; 5(119):1-9.

24- Alwabr GM \& Al-Moayed EE.Prevalence of intestinal parasitic infections among school children of Al-Mahweet Governorate, Yemen. European Journal of Biological Research.2016; 6(2): 64-73.

25- Ojurongbe O, Oyesiji KF, Ojo JA, Odewale G, Adefioye OA, Olowe AO, Opaleye OO, Bolaji OS and Ojurongbe TA .Soil transmitted helminth infections among primary school children in Ile-Ife Southwest, Nigeria: A cross sectional study. International Research Journal of Medicine and Medical Sciences.2014; 2(1): 6-10 